\title{
Tourism in Apuseni Mountains (Romania) - A technical proposal
}

\author{
Authors' Contribution: \\ A Study Design \\ B Data Collection \\ C Statistical Analysis \\ D Data Interpretation \\ E Manuscript Preparation \\ F Literature Search \\ G Funds Collection

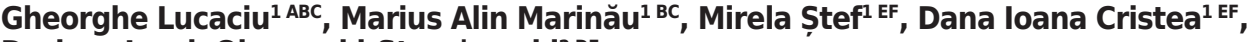 \\ Dariusz Jacek Olszewski-Strzyżowski² DE \\ ${ }^{1}$ Faculty of Geography, Tourism and Sport, University of Oradea, Oradea, Romania \\ 2 Gdansk University of Physical Education and Sport, Gdansk, Poland
}

\section{abstract}

Background: The article presents the results of research on mountain tourism in the Apuseni Mountains in Romania, especially in the field of safety and health (physical condition) of participants of expeditions to the mountains and their knowledge about the risks that may be encountered in these destinations and the methods of informing about these threats (proposed markings and information about hazards in the mountains, and placed on hiking trails).

Material and methods:

45 volunteer young people were involved in the research. The methods used were: 1) field testing method; we monitored the evolution of the heart rate and correlated it with the geographical area; 2) survey / questionnaire method; through a questionnaire, were subjectively identified the potentially hazardous areas and the reasons why they were considered as such; 3 ) direct observation method; we made a correlation between the subjective physiological response (accelerated breathing, suffocation, sweating) and the area in which they occurred.

Results: Monitoring the evolution of the heart rate has allowed highlighting areas where prolonged physical exertion can generate a state of fatigue that can become acute, thus promoting decreased ability to pay attention and focus. The recommendation that accompanies the proposed tourist sign on several levels of intensity, induces the "obligation" of the recovery break, thus inducing the return of attention and the ability to concentrate. Other areas that may present a significant potential of risk or danger to tourists, by slipping or overloading muscles or areas with a complex geographical structure that require specific skills: balance, muscle strength, etc., have been identified using the questionnaire.

Conclusions: Based on all the information collected, depending on the characteristics of the type of risk, we propose to complete the catalogue of tourist signs with more specific information. We assume that informative signs that we propose and the additional information they contain can contribute to the avoidance of some limit situations that would determine the occurrence of some incidents or accidents. The better educated and informed tourists are, the safer their way will be.

Key words: mountain tourism, Apuseni mountains (Romania), complex effects.

\section{article details}

Article statistics: Word count: 2,193; Tables: 0; Figures: 5; References: 26

Received: June 2021; Accepted: October 2021; Published: November 2021

Full-text PDF: http://www.balticsportscience.com

Copyright $\odot$ Gdansk University of Physical Education and Sport, Poland

Indexation: Celdes, Clarivate Analytics Emerging Sources Citation Index (ESCI), CNKI Scholar (China National Knowledge Infrastructure), CNPIEC, DOAJ, EBSCO - Central \& Eastern European Academic Source, EBSCO - SPORTDiscus, EBSCO Discovery Service, Google Scholar, Index Copernicus, J-Gate, Naviga (Softweco, Primo Central (ExLibris), ProQuest - Family Health, ProQuest - Health \& Medical Complete, ProQuest - Illustrata: Health Sciences, ProQuest Nursing \& Allied Health Source, Summon (Serials Solutions/ProQuest, TDOne (TDNet), Ulrich's Periodicals Directory/ ulrichsweb, WorldCat (OCLC)

Funding: This research received no specific grant from any funding agency in the public, commercial, or not-for-profit sectors.

Conflict of interests: Authors have declared that no competing interest exists.

Corresponding author: Lucaciu Gheorghe, Prof. Costaforu Gheorghe Street, No. 8, Ap. 9, Oradea, Romania; Phone no: +40765231404 ; e-mail: ghita_lucaciu@yahoo.com

Open Access License: This is an open access article distributed under the terms of the Creative Commons Attribution-Non-Commercial-NoDerivatives 4.0 International (https://creativecommons.org/licenses/by-nc-nd/4.0/), which permits use, distribution, and reproduction in any medium, provided the original work is properly cited, the use is non-commercial and is otherwise in compliance with the license. 


\section{INTRODUCTION}

The reality of the orientation of more and more people towards physical activity specific to leisure and to travel for tourism purposes is now accessible to all and is undoubtedly due to the need to find a way to compensate for the characteristics of modern human life (pollution, nervous overload, inadequate nutrition or overeating, sedentary lifestyle, etc.) [1], in the sense of combating unwanted or harmful effects [1].

UNWTO defines tourism as a "social, cultural and economic phenomenon which entails the movement of people to countries or places outside their usual environment for personal or business/professional purposes" [2].

Why tourism? Beyond the perspective (economic, social, professional, environmental, etc.), tourism of today is an essential component of life for more and more countries and people. Receptive to the transformations of the contemporary world, tourism evolves under their impact, its dynamics being integrated in the general development process. Moreover, through the human and material potential involved and the effects on the areas of interference, tourism acts as a stimulating factor for development. Romanian tourism is no exception. Official data highlights for the period 2010-2019, the increase in the number of visitors and tourists (Fig. 1) from 7.5 million to approx. 13 million (73\%), with an increased financial contribution from $\$ 1.8$ billion to over $\$ 4$ billion (222.2\%) [3]. As a macroeconomic indicator for the period 2011-2017, the same data (Fig. 2) indicate a contribution of tourism to Romania's GDP, increasing from 1.7\% to 2.8 [4]. Given the implications (employers, employees, infrastructure and environment, etc.), it is clear that tourism is an economic opportunity for any nation in the world.

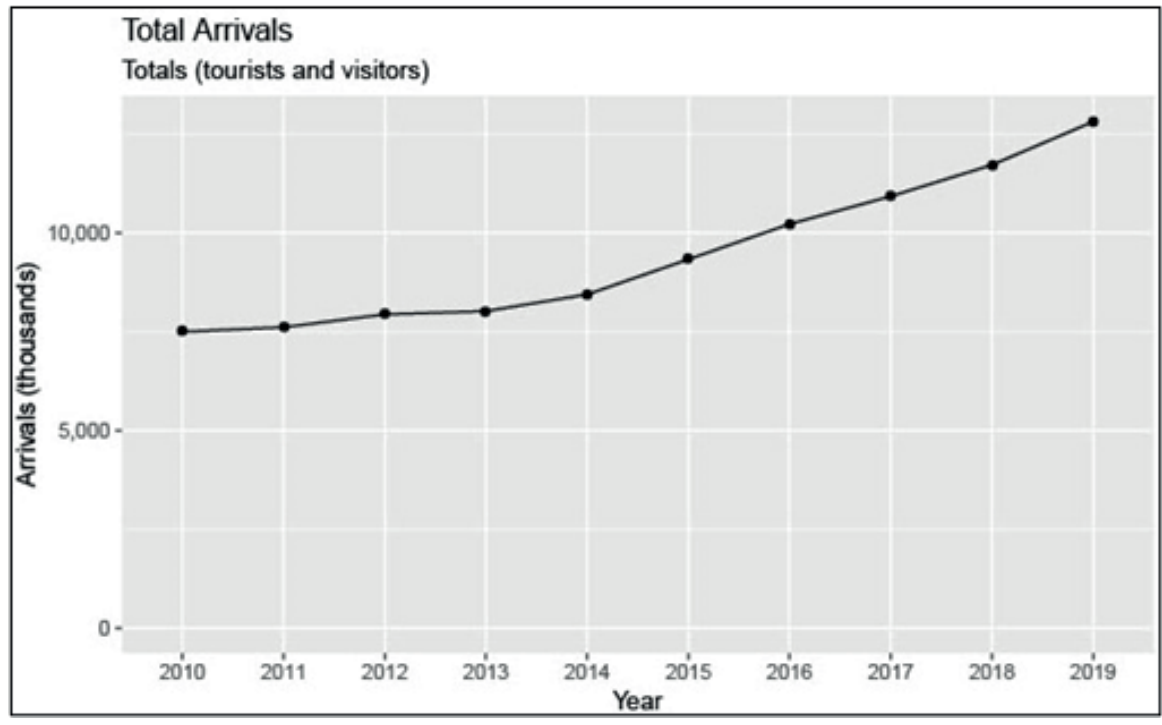

Fig. 1. Trend in the number of visitors and tourists in Romania

(https://webunwto.s3.eu-west-1.amazonaws.com/s3fs-public/2020-10/romania.pdf) 


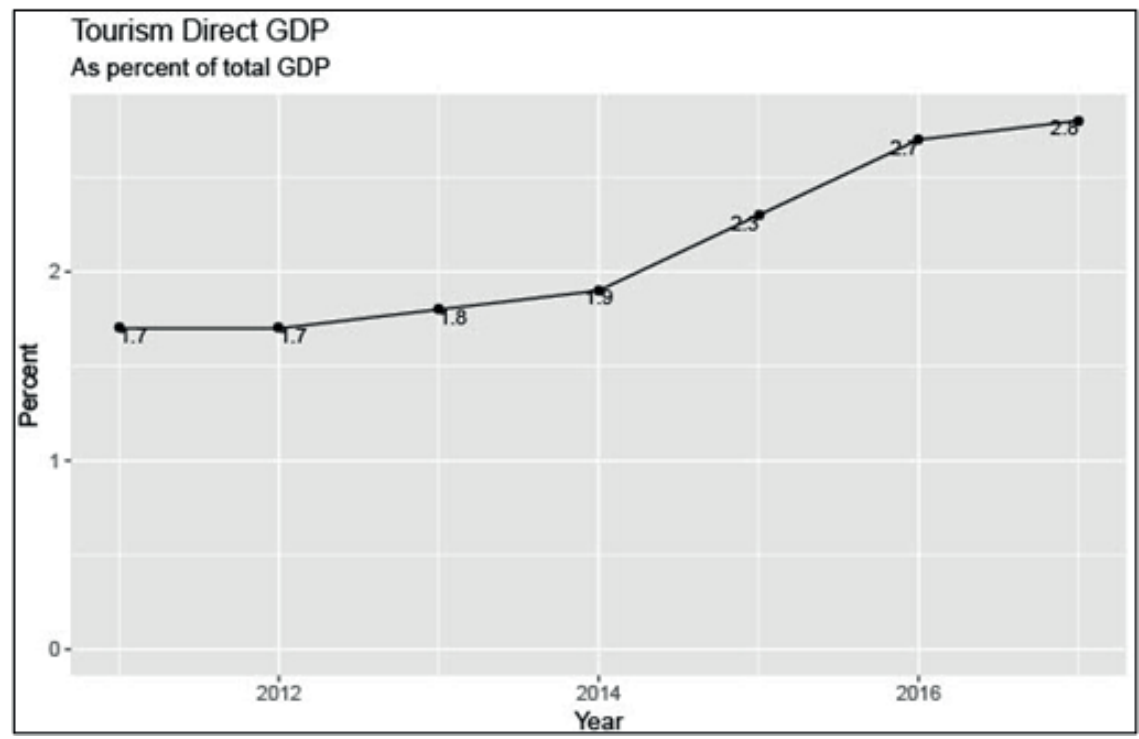

Fig. 2. Trend in the tourism contribution to the Romanian GDP

(https://webunwto.s3.eu-west-1.amazonaws.com/s3fs-public/2020-10/romania.pdf)

Why mountain tourism? First of all, because mountains of different altitudes and geographical locations, with a great variety of forms, climatic conditions, with rich and unique heritage of human culture, are found on every continent, almost in every country, from the Equator to the Polar Circles (and in Romania they are particularly well represented) [5]. All the characteristics of modern life (industrialization, cybernetization, computerization, reduction of physical effort, pollution, stress, etc.) and the consequences generated by human evolution, especially in the last decades, are other possible answers to the above question. Moreover, mountain tourism has a major advantage through its wide accessibility [6]. Those who want to practice tourism are not conditioned by certain qualities, habits or physical abilities, and there are no age limits. Accessibility derives from the possibility of choosing the route, its difficulty depending on the individual capabilities, the absence of the competitive character, etc.

Why tourism in the Apuseni (Western) mountains in Romania? In the Carpathian Mountains, there are 56 routes with high difficulty, the most numerous (33) being located in the Apuseni Mountains [7]. Limestone rocks, spread over about $4000 \mathrm{~km}^{2}$ in the mountains of Romania, including the Apuseni Mountains, as well as in some plateaus, generated a karst relief representative for the temperate region of Europe. Of the 80 gorges and of tourist interest in Romania, 15 are also in the Apuseni Mountains area. In addition to the presence of gorges, the karst relief substantially increases its contribution to the tourist potential of Romania due to the existence of caves and avens. Although the surface of karst formations is relatively small compared to other countries, the endocarstification index is high (approx. 3 caves $/ \mathrm{km}^{2}$ of calcareous soil). Of over 11,000 caves inventoried so far, over 145 have tourist attraction resources, 46 of them being within the geographical limits of the Apuseni Mountains [8]. Adding the many special landscapes and viewpoints, the arguments could continue.

Motor activities performed outdoors are interactive activities that simulate real situations and involve solving tasks, being in fact essentially the practical materialization of the method of experiential learning, which involves the use of all senses and skills; they occur generally, but not exclusively, by exposure to the demands of the natural environment, causing physical, mental and emotional effects [9]. As a result of involvement in these types of activities, participants develop or improve a range of skills, abilities and competencies that contribute to improving individual performance, and team members' awareness of 
obstacles that hinder teamwork contributes to improving its performance, both in the exercise and in "real life" [10].

Tourists are attracted to the mountains for countless reasons: from the climate and fresh air, to the beauty of the landscapes, the diversity of landforms and geological phenomena, local traditions and simplicity of life or even specific opportunities to practice different sports [11, 12]. However, they have influenced public policies in many countries towards the development of tourism as a tool for the conservation of culture, biodiversity and sustainable development, but also generating important questions:

- does tourism contribute to the sustainable development of mountain areas?

- who benefits (in economic terms) from mountain tourism?

- are biophysical resources in mountain areas degraded by carrying out actions specific to mountain tourism?

- does mountain tourism positively or negatively affect society and local communities?

The answers are particular and probably specific to different types of tourism and should be of concern to authorities everywhere.

Given that health is seen not only as a situation characterized by the absence of disease, but as a positive concept that includes physical, social and emotional well-being, the importance of physical activity for health is already clearly established and quite well known. Yet, despite this reality, the share of sedentary people is constantly increasing in all age groups and which is particularly worrying - especially in the younger generation, as a consequence of lack of exercise and an inadequate lifestyle, with particularly harmful effects. The major impact of the global Covid-19 pandemic on all aspects of modern life makes concerns about the effects of tourism (including mountain tourism) perhaps more important than before.

\section{MATERIAL AND METHODS}

\section{RESEARCH OBJECTIVES}

The study is part of a complex research carried out in the period 2008-2009, whose general objective was to highlight the effects of mountain tourism in as many aspects as possible (sociological, psychological, physiological, educational). The specific objective of this study, derived from the general objective during the research, is to define the profile of mountain routes from the perspective of the involved physical effort and the necessary skills, as well as to find practical tools that could reduce the number of incidents specific to mountain tourism by adding signs in the map key. These additional signs refer to aspects related to the intensity, volume and/or complexity of physical effort along the marked routes.

\section{SAMPLE}

The sample consisted of 45 young people ( 21 girls $-46.6 \%$, 24 boys $-54.4 \%$ ) aged between 19 and 22 years (mean age 20.3 years), first-year students in the specialization of Physical Education and Sports, University of Oradea, with a similar level of motor skills who volunteered to participate in this study [1].

\section{METHODS}

During walking on mountain trails, the evolution of the heart rate was monitored using the Polar H 10 Heart Rate Monitor (Fig. 3); heart rate peaks were identified, correlated with geographical areas, and they were marked on the map.

The observation method (direct observation) was also used to observe spontaneous reactions in different contexts generated by walking on mountain trails (accelerated 
breathing, suffocation, sweating, etc.), relational and communicational evolution both within the group and at the interpersonal level and also to identify potentially hazardous areas.

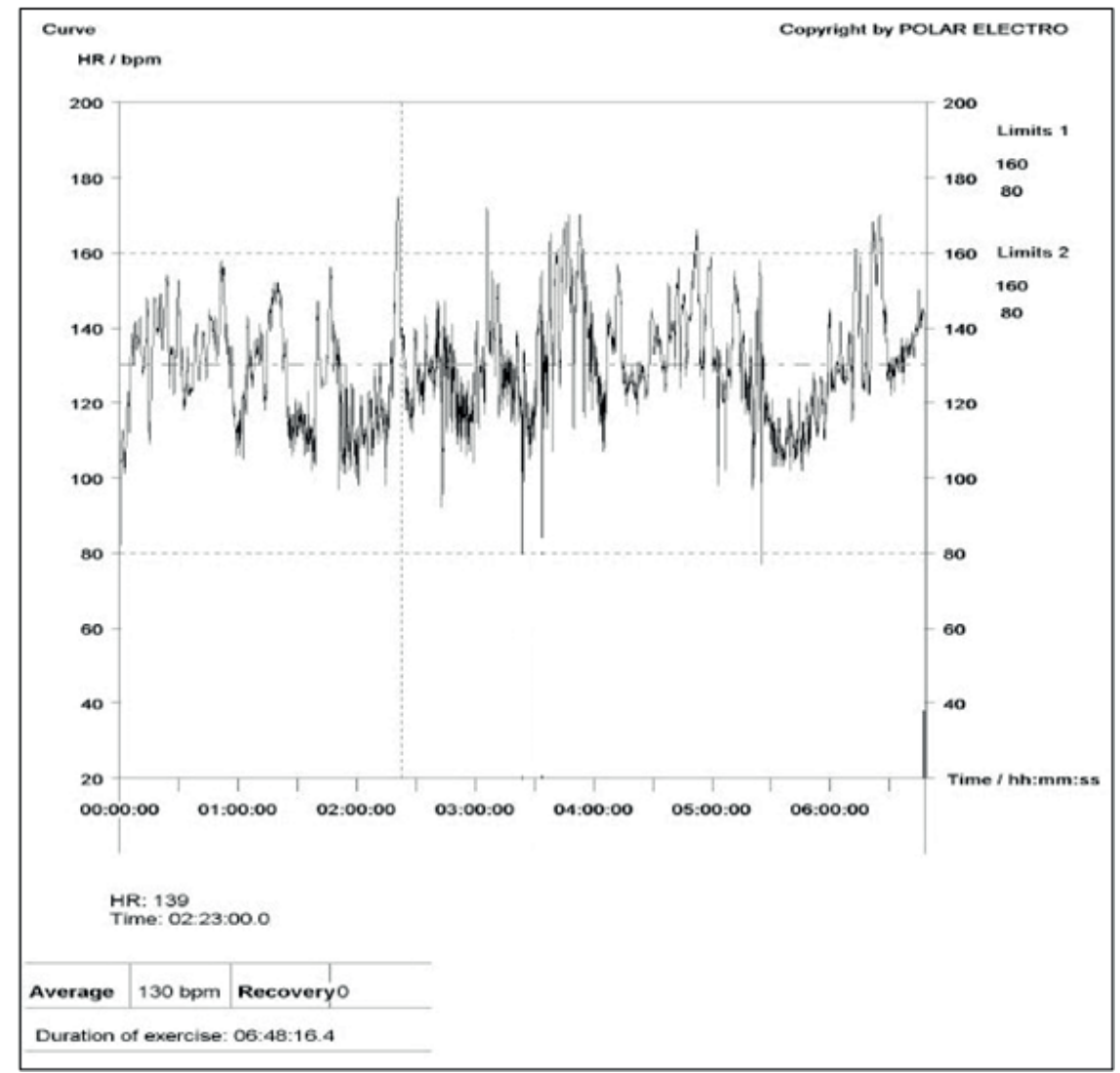

Fig. 3. Evolution of the heart rate on a mountain trail

A questionnaire (a sociological survey method) was also used to highlight the subjects' subjective opinion about the areas with the highest risk potential. The locations that met over $50 \%$ of the opinions as potentially risky were marked on the map.

\section{RESULTS AND DISCUSSION}

In addition to the economic consequences, tourism also has a deep socio-human significance. Its action is exerted both on tourists and on the population in the target areas, reflecting in terms of consumption, education [11], leisure [13], quality of the environment [14-16], interethnic cultural relations, etc.

The world we live in is extremely complex, dynamic and constantly changing, characterized among others by a great diversity of biunivocally determined relationships, individual and collective values, ideals and lifestyles, different ways of action. The research as a whole was an attempt to highlight the relationship that can be created between physical exercise on the one hand and active tourism and the natural environment on the other hand, a topical concept in other geographical areas, but whose theoretical and practical aspects require an adequate substantiation, which allows its advancement around specific curricular areas and which could connect physical activity with ecotourism, biotourism, agrotourism, cultural tourism, etc., respectively with current forms of active tourism (mountain tourism, water tourism, adventure tourism, etc.), all of which respond to the needs of structure and content of active tourism [1]. 
The main study aimed to highlight the effects of mountain tourism organized in the form of a tent camp, from a biological, social, economic, educational point of view [9], awareness of potential risks and highlight the risks to which tourists are exposed depending on the particularities of the geographical area and, subsequently, the proposal to introduce new signs in tourist maps, according to the intensity, volume and/or complexity of physical effort along the marked routes [1].

Between 2010-2018, the evolution of the number of accidents on mountain trails [18] was increasing, involving both Romanian and foreign tourists. Accidents occurred due to slipping, falling, loss of orientation and entering dangerous areas, lack of lighting, inadequate equipment, etc. and resulted in lower limb sprains, limb fractures, contusions and even loss of lives. Often, tourists approach mountain tourism as a regular activity that does not require adequate training $[19,20]$, which is a major cause of accidents, so the importance of education [21] and the educational role of mountain tourism [22-24] are essential in ensuring the full bodily integrity of tourists. On the other hand, we consider important the correlation between the own motor level and the level of difficulty and complexity of the chosen route. Informed choices can be made by testing the level of motor skills and by thorough knowledge of the particularities of the chosen routes.

There are sufficient reasons to justify the concern and involvement of all responsible factors in making tourist trails safe, including by optimizing the information effect provided by tourist maps. Our approach lies in this context.

Recently, in the mountains of Romania there have been countless incidents, both during the summer (minor accidents, due to carelessness or ignorance of the area, but also serious ones: simple or multiple fractures, consequences of falls from heights, heart attacks and even deaths), as well as in winter (due to improper equipment or avalanches). Just in 2019 alone, mountain rescuers in Romania intervened in 7170 rescue actions, in which 8927 people were rescued. However, there were 69 deaths [25]. On the other hand, most of the times, the inattention causing accidents is determined or favoured by the early onset of accentuated fatigue [20]. This fact is determined by not knowing or overestimating the physical condition, or not knowing the characteristics of mountain trails.

The informative details (signs) that we propose (Fig. 4), can contribute to the avoidance of some limit situations that would determine the occurrence of some incidents or accidents, by highlighting:

- areas with steep climbs (ramps), which require a high emphasis on the cardiovascular system for periods longer than 2-3 minutes (heart rate above 140-160 beats / minute) and which must be known to people with cardiovascular disease;

- areas with steep descents (slopes), which overload the muscular and articular system and / or which require adequate footwear and "step down";

- areas with passage over unstable parts (gravel, boulders, etc.), which require balance and extra attention;

- areas requiring climbing with ropes or passageways with chains, which require a good level of strength of the upper limbs;

- crossing semi-arranged bridges, which require increased attention and a good balance;

- caves or potholes with forbidden access or not arranged for visiting;

- caves or potholes open to visitors but unlit, requiring its own light source;

- facilities offered by the cottages located on the mountain trails (accommodation, food, electricity, mobile phone signal or internet);

- technical areas requiring special equipment, thus being accessible only to specialists;

- trails or sections of trails prohibited in winter. 


\begin{tabular}{|c|c|}
\hline$\uparrow^{1}$ & $\begin{array}{l}\text { Medium level ascent! HR can reach } 140 \text { beats/min.; recommended } \\
\text { pace: } 50-60 \text { steps/min. }\end{array}$ \\
\hline$\uparrow^{2}$ & $\begin{array}{l}\text { Difficult ascent! FC can reach } 160 \text { beats } / \mathrm{min} \text {; recommended pace: } 30 \text { - } \\
40 \mathrm{steps} / \mathrm{min} \text {; rest required at max. } 30 \mathrm{~min} \text {. }\end{array}$ \\
\hline $4^{3}$ & $\begin{array}{l}\text { Dangerous ascent! HR can exceed } 180 \text { beats } / \mathrm{min} \text {; recommended pace: } \\
15-20 \mathrm{steps} / \mathrm{min} \text {; rest required at } \max .20 \mathrm{~min} \text {. }\end{array}$ \\
\hline$\downarrow_{1}$ & Medium level descent! Caution is advised. \\
\hline$b_{2}$ & Dificult descent! It is recommended to descend on side; \\
\hline$t_{3}$ & $\begin{array}{l}\text { Dangerous descent! It is recommended to descend on side; avoid } \\
\text { trampling on tree roots. }\end{array}$ \\
\hline 《 & Careful! Ascent/descent on unstable boulders. \\
\hline 乡 & Rope climbing; required strength of the arm muscles. \\
\hline N & Chain passage; minimum strength of the arm muscles is required. \\
\hline & Suspension bridge, without railing; balance required. \\
\hline$\Omega$ & Cave not arranged for visiting. \\
\hline & Light source required. \\
\hline $\mathbf{T}$ & $\begin{array}{l}\text { Chalet (C-accommodation; M-food; E-electricity; T-mobile signal; } \\
\text { WF-internet signal). }\end{array}$ \\
\hline & Special techniques and/or materials/equipment required. \\
\hline 0 & Prohibited route in winter. \\
\hline
\end{tabular}

Fig. 4. Possible signs

In order to materialize the proposals aiming at the introduction of new tourist information/ signs, we used the real map of the area where the research took place (Fig. 5) [26].

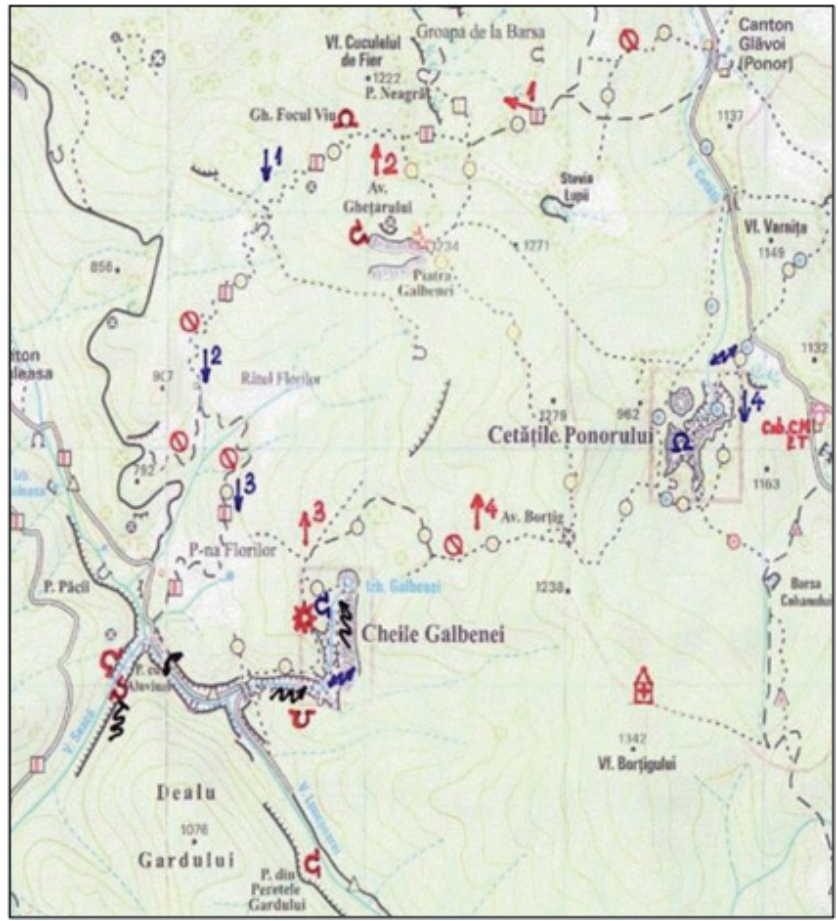

Fig. 5. The map of Padis Area in the Apuseni Mountains, adapted 


\section{CONCLUSIONS}

It should be hoped that wise and prudent mountain tourism (in this case in the Apusemi Mountains) by tourists will result in fewer accidents, and the marking of tourist routes proposed by the authors (information, directions, markings, signs, pictograms, etc.) in a decisive manner, can improve this situation.

Because the most important thing is to educate tourists and make them aware that mountain tourism is not only pure pleasure, but also many dangers lurking in the mountains (more education and information today means fewer accidents on mountain trails tomorrow).

\section{ACKNOWLEDGEMENTS}

Some of the data are part of the doctoral thesis of the first author. Thanks to Mr. Gheorghe Simion, $\mathrm{PhD}$, for accepting the research topic and for the proposed suggestions.

\section{REFERENCES}

[1] Lucaciu G. Filozofia timpului sau viața între mod și stil. [The philosophy of time or life between way of life and style] Oradea: University of Oradea Publishing; 2013. Romania.

[2] Lucaciu G. Contribuții privind educarea socio-motrică a studenților prin mijloacele turismului de munte. Teza de doctorat. [Contributions regarding the socio-motor education of students through the means of mountain tourism. PhD Dissertation]. Pitești: University of Pitești; 2009. Romania.

[3] Definition of tourism. [Available at https://www.unwto.org/glossary-tourism-terms] [Accessed on 29 July, 2021].

[4] Romania - Tourism statistics. [Available at https://webunwto.s3.eu-west-1.amazonaws.com/s3fs-public/2020-10/ romania.pdf] [Accessed on 29 July, 2021].

[5] Li Q, Wu M. Tourists' pro-environmental behaviour in travel destinations: benchmarking the power of social interaction and individual attitude. J Sustainable Tourism. 2020;28(9):1371-1389. https://doi.org/10.1080/09669582.2020.173 7091

[6] Farkić J, Filep S, Taylor S. Shaping tourists' wellbeing through guided slow adventures. J Sustainable Tourism. 2020;28(12):2064-2080. https://doi.org/10.1080/09669582.2020.1789156

[7] Lucaciu G. Mountain tourism-practice and effects. Palestrica of the third millennium-Civilization and Sport. 2014; 15/1:36-39.

[8] Lucaciu G, David L, Lucaciu S, Pop AC. Effects of mountain tourism practice. University of Oradea Annals-Physical Education and Sport Fascicle. 2014;XXIV:82-86.

[9] Lucaciu G, Marinău MA, Ștef M, Dragoș PF. Changes in the group's social structure in mountain tourism. Balt J Health Phys Act. 2014;6:56-61. https://doi.org/10.2478/bjha-2014-0007

[10] Sven R. Travelling in the wilderness: Experiential learning and youth at risk. Youth Stud Austr. 1993;12(3):14-27.

[11] Daas KL, McBride CM. Participant Observation: Teaching Students the Benefits of Using a Framework. Communic Teach. 2014;28(1):14-19. https://doi.org/10.1080/17404622.2013.839045

[12] Mascarenhas M, Pereira E, Rosado A, Martins R. How has science highlighted sports tourism in recent investigation on sports' environmental sustainability? A systematic review. J Sport Tourism. 2021;25(1):42-65. https://doi.org/10 .1080/14775085.2021.1883461

[13] Milman A, Zehrer A. Exploring visitor experience at a mountain attraction: The Nordkette mountain in Tirol, Austria. J Vacation Market. 2018;24(2):172-186. https://doi.org/10.1177/1356766717691805

[14] Bastian O, Stein C, Lupp G, Behrens J, Renner C, Grunewald K. The appreciation of nature and landscape by tourism service providers and visitors in the Ore Mountains (Germany). Landscape Online. 2015;41:1-23. https:// doi.org/10.3097/LO.201541

[15] Gao Y, Ma Y, Bai K, Li Y, Liu X. Which factors influence individual pro-environmental behavior in the tourism context: Rationality, affect, or morality? Asia Pac J Tourism Res. 2021;26(5):516-538. https://doi.org/10.1080/10941665.20 21.1876117

[16] Li Q, Wu M. Tourists' pro-environmental behaviour in travel destinations: benchmarking the power of social interaction and individual attitude. J Sustainable Tourism. 2020;28(9):1371-1389. https://doi.org/10.1080/09669582.2020.1737091

[17] Lucaciu G. Physical and psycho-social changes in mountain tourism. Saarbrücken: LAMBERT Academic Publishing; 2014.

[18] Accidente turistice în zone montane. [Tourist accidents in mountainous areas] [Available at https://www.agerpres.ro/ documentare/2018/07/22/accidente-turistice-petrecute-in-zone-montane-cronologie-2010-2018--148743] [Accessed on 6 August, 2021].

[19] Duglio S, Beltramo R. Quality assessment in the Italian mountain huts. Eur J Tourism Res. 2014;8:115-135.

[20] Kenney WL, Wilmore J, Costill D. Physiology of Sport and Exercise, 7th Edition. Champaign: Human Kinetics Publishers; 2019.

[21] Ardoin NM,Wheaton M, Bowers AW, Hunt CA, Durham WH. Nature-based tourism's impact on environmental knowledge, attitudes, and behavior: a review and analysis of the literature and potential future research. J Sustainable Tourism. 2015;23:838-858. https://doi.org/10.1080/09669582.2015.1024258 
[22] Arnegger J, Woltering M, Job H. Toward a product-based typology for nature-based tourism: a conceptual framework. J Sustainable Tourism. 2010;18(7):915-928. https://doi.org/10.1080/09669582.2010.485680

[23] Bouchet P, Lebrun AM, Auvergne S. Sport tourism consumer experiences: a comprehensive model. J Sport Tourism. 2004;9(2):127-140. https://doi.org/10.1080/14775080410001732578

[24] Jensen Ø, Lindberg F, Østergaard P. How can consumer research contribute to increased understanding of tourist experiences? A conceptual review. Scand J Hospital Tourism. 2015;15:9-27. https://doi.org/10.1080/15022250.20 15.1065591

[25] Romania rescue service - 2019 activity report. [Available at https://www.salvamontromania.ro/upload/raport de activitate_2019.pdf] [Accessed on 29August, 2021].

[26] Tourist map of Padiș area. [Available at https://www.avenzamaps.com/maps/417276/zona-padis-din-muntii-bihor] [Accessed on 26 July, 2021]. 